\title{
1970～94年の芥川賞受賞作品群にみる自然景観イメージとその変遷 \\ IMAGES OF LANDSCAPES AND THEIR TRANSITIONS \\ IN. AKUTAGAWA PRIZE WORKS FROM 1970 TO 1994
}

\author{
池田朋子*, 大貝 彰** \\ Tomoko IKEDA and Akira OHGAI
}

\begin{abstract}
A novel expresses a world as a model with concrete and universal descriptions, which includes expressions of landscapes. In this study, we analyze fifty-five novels which won Akutagawa Literary Prize from 1970 to 1994 , to understand images of landscapes in recent years. Landscapes in the text are categorized into nine items and understood with stages of stories and periods. First, they are grasped quantitatively by the level of words. Then, reading stories around the words lead us to understand the meaning of items of the landscapes. As the results, after high economical growth, landscapes and their meanings decrease such as mountains as boundaries, rivers with plays, hills for understanding oneself relatively in the town and fields viewed on one' $s$ ways. Landscapes such as flowers, woods and skies which have been still left become to get more meanings.
\end{abstract}

Keywords: novel, image of landscape, literary prize, life in the present day 小説、自然景観イメージ、文学賞、現代生活

\section{1.はじめに}

(1) 背景と目的 人はカメラのように視野にある物の全てを見ている わけではなく、感情や無意識の淘汰によって選択された物を見てい る。その中で何らかの印象に残ったものが景観のイメージとして記 憶に残り、その蓄積が人にとって重要な心象風景になると考えられ る。近年多くの景観研究がなされてきたが、景観を構成する各要素 が人の心の中でどのような意味を帯びているかは充分に明らかにさ れているとは言えない。このことが景観計画・設計における方向性 や合意形成といったソフトな技術面の遅れをもたらしていると思わ れる。本研究は、経年的に日本を代表するような小説を対象に、そ こに書かれた景観を分析することで、社会的に共有された自然景観 イメージを年代変化と共に明らかにすることを目的としている。具 体的には、社会的に影響力が強いと考えられる芥川賞受賞小説群を テクストとして、自然景観に関する表現の出現傾向を舞台や年代と 関連させながら定量的に把握し、自然景観の各要素の特徵とそれに 付随する意味、またその変遷を捉える。

描写された景観を分析した代表的な既往研究には、浮世絵やヨー ロッパの風景画を対象として伝統的な美観の構成原理を解明したも の”、校歌を対象として地域景観の構造を解明したもの市な゙がある。 前者は、抽出された景観要素から「絵になる景観」の構成原理の解 明を試みている。しかしテクストの持つ性質から、それに付随する
イメージまでは解読できない。一方後者は景観要素の組み合わせか ら地域景観構造を分析しているが、校歌の内容から各要素に託され た意味やその要素により構成される場面の分析まではなされていな い。心象風景としての景観イメージを把握するには、その景観要素 の書かれた場面やそれに託された意味を解釈する必要がある。また、 戦後の経済発展期を通じて町の構造やそこでの生活等が大きく変化 してきたことを考えると、景観計画段階の基礎知識の一部として、 現在につながる現代の生活に関わる景観イメージに関しても知見を 得る必要があると考える。このような意味での景観イメージは大き く都市景観イメージと自然景観イメージに分けられるが、ここでは 日本では景観の中でも特に自然景観が卓越していると考えられる注1 ため、自然景観のみに着目した。

一方、描写された景観イメージの変遷を扱った研究には、海の歌 謡曲 ${ }^{3)} 、$ 浮世絵4に表現されたイメージの型の変化を分析したものが ある。これらは類型やその構成の変化を主に分析していて、自然景 観に託された意味の変化を直接具体的に分析したものではない。

このような背景から、本研究は小説を分析対象として近年の自然 景観イメージとその変遷の解明を試みる。

(2) 小説への着目 さて、ここでは小説を景観イメージ分析の対象と する意味について述べる。小説は現実をモデル化して表す芸術の一 形式である5)。人間はその歴史の始めから物語ることによって世界
$*$ 豊橋技術科学大学建設工学系 大学院生 $\cdot$ 工修

** 豊橋技術科学大学建設工学系 助教授・工博
Graduate Student, Dept. of Architecture and Civil Eng., Toyohashi Univ. of Technology, M. Eng.

Assoc. Prof., Dept. of Architecture and Civil Eng., Toyohashi Univ. of Technology, Dr. Eng. 
を捉えてきた5.6)。書かれ読まれるエクリチュールとしての小説は近 代に成立したと考えられ、複雑な現状の人間や人間体験を認識し表 現することに長けた形式である ${ }^{5.7 .8)}$ 。小説では、読み手を作品の内部 世界へ引き込みその存在感を感じさせるしくみとして、作品の舞台 が設定され、描写される9。これは生の相似物としてつくられるが、 類似は完全な再現ではなく、メタフォア、メニトミー、コントラス トの作用によって全体と同一視された特殊なものだけが再現される 10)。小説ではこの全ての作業は言葉によって成され、言葉は心象を 直接生成し、そのまま表す力を持っている"1。このように、小説で はテーマに対応して書くべきことが選択され、現実がことばによっ て構造化され、モデル化されていると言える5。これは人間とそれ を取り巻く環境の構造を作品独自の視点で一つのケースとして明ら かにしたものと考えられる。それは個別で特殊な具体的な物事の表 現であり ${ }^{22}$ 作品の中のことばや文章はその書き手の態度を根底にひ そめていで(3)、作られたモデルは現実の現象のモデルであると同時 に作者の人格のモデルでもあるら”。かし、一方これは他者への伝 達を前提として作られ、多くの読者に体験され共有されて、普遍的 で代表的な体験の一つのケースとして社会的に存在するようになる と考えられる。このように小説は、つきつめれば「いかに生きるか」 というテーマがそれぞれの個別なケースとして具体的に展開する特 定の舞台において、人間とそれを取り巻く環境を描いた普遍性のあ るテクストと考えられる。従って小説中に表現された景観を分析す ることで、ある時点で総合的に組み立てられている景観イメージの 要素間の相対的な関係や、個々の景観に付随する意味や価值が、具 体的で同時に普遍的な現象として明らかにされると考えられる。

2. 方法

\section{1 テクストの選定}

芥川龍之介賞受賞作品群は、多くの読者に共有され、また文壇の 権威からも支持され、各時代を代表する純文学の小説である。

純文学というジャンルで小説は、「どうしても書かずにはいられ ない」という欲求の中で自発的に書かれる。従って娛楽の要素など に表現を影響されず、純粋に既存の環境の中での人間体験をつきつ めて書いていると考えられる。ここで芥川賞は、60年以上の歴史を 持つ、新人の純文学短編小説に与えられる賞である。日本で最も権 威があり社会的影響力の大きい伝統ある賞と考えられる 受賞作は時代を代表し、レベルやスタイル、評価などの条件の揃つ た作品群と考えられ、分析対象としてふさわしい湤2。

ここでは現在に近い時代に分析の主眼を置くため1970-94の24年間 に芥川賞を受賞した55作品をテクストとする。芥川賞は年2回選考 発表があるが、ダブル受賞や該当作なしの時もあり、1年間に4-0作 品の受賞作がある。小説が成立した時期と小説の舞台となった時代 は必ずしも一致しないので書かれた時代は戦前から現代にわたる。 2.2 分析手法

ここでは、小説を分析対象とした既往研究の手法を簡単にまとめ、 本研究の分析手法の概略を述べる。

(1) 既往研究とその手法 小説から景観イメージを分析したもので はないが、随筆から風景 ${ }^{15)}$ を、小説から建築体験(1.17)を分析した研究 がある。これらは定性的な手法で書かれた内容を哚く読み込んでい る。また、建築空間情緒 ${ }^{18}$ を分析した若山らの研究では、小説等に 出現した単語が定量的に把握され、客観的な結果を出している。
一方拙稿(9)でこれらの既往研究をふまえて小説から景観イメージ を定量的に分析する方法論を提案し、2つのケーススタディに適用 した。具体的には、まず景観に関する語の出現頻度を把握し、続い てこの結果をより染く解釈するため、文脈に戻って定性的な読み込 みを行った。そして作品群で共通する語や意味内容を定量的に重ね 合わせることで、できるだけ客観的に普遍性の強い景観要素や構成 を抽出できることを示した。また著者の属性に関わらず共通する景 観の要素や構成が多くみられることも示した。つまり、小説は著者 の個人的な経験を越えて普遍的な景観をモデル的に表現していると 考えられる。

(2)本研究の手法 これらを受けて本研究では、作品群の中から定量 的に共通する記述を取り出して景観の特徴を捉える。ここでは、 1.(2)の小説の表現の特徴に関する考察と、拙稿 ${ }^{(9)}$ の結果より、芥川 賞を受賞した作品は全て等価なものとして扱う注引。

分析は詞句レベルと文脈レベルの二段階で行う。詞句レベルの分 析では、どのような景観が多く書かれていたか、またそれがどのよ うに変化しているかといった出現傾向を把握する。次の文脈レベル の分析では、その具体的な意味内容や質的な变化を把握する。

ここで、分析の単位について述べ、二段階の分析方法を説明する。 小説はリニアに連続したテクスト形式を持つ。従ってその内容を定 量的に扱うには、それを意味上のまとまりに切り分ける必要がある。 小説に書かれた景観は、「舞台」となる場所、その中での1シーン となる「場面」、そこでの「視対象」(リニアに述べられていくその 時々の物事）のシークエンスという意味の枠組みで捉えることがで きる。これを小説内の記述に対応させると、視対象は名詞を中心と した「詞句」のレベルに対応し、これが連続して文章の塊あるいは 節のレベルにあたる「場面」が作られる。これは入れ子状により大 きい場面や舞台に含まれていく。そこでまず、どのような自然景観 の要素が書かれているかを単純に把握するために、最も小さい意味 単位である詞句レベルで景観の記述の有無をみる。景観は舞台を説 明するために表現されていると考えられるので、これを舞台ごとに 集計する。これが詞句レベルの分析である。

次に各々の景観要素の具体的な内容とそれに託された心象を明ら かにするため、文脈を読み込む。各々のことばは作品内で独自の意 味づけを持たせられていて、その意味や重さはテクストを構成する ことばの関係の中で相対的に決められる2()。これは人間が読書する という行為を通じてしか今のところ理解されないものである。ここ では場面や舞台のレベルで、景観の見え方や託された心象を切り口 としてコノテーション（意味）を読み取り、多くの作品で共通する コノテーションを抽出する。これが文脈レベルの分析である。

\section{3. 詞句レベルの分析}

\section{1 分析方法}

(1)自然景観要素の抽出法 詞句の単位で自然景観に関する表現（シ ニフィアン)は、例えば「樹」「樹木」「木」など場面ごとに異なる 可能性がある。しかしそのデノテーション（明示的な意味）は同じ である。そこで既往研究2)を参照して表-1に示す 9 項目の景観要素の カテゴリーを設定し、これに属するデノテーションがあればシニフ イアンの違いに関わらずその景観要素の記述があったと判断する。 (2) 舞台の分類枠 テクスト内の舞台は、森や湖といった場所、また 主人公の家のある場所とそこから遠い場所、といった様々な舞台が 
考えられ、これらの捉え方は分析の視点によって異なってくる。こ こで自然景観は舞台の説明のための大道具や小道具のようなものと 考えられる。そのため、自然景観の記述の有無は都市や農村といっ た舞台の性質に影響を受けると考えられる。また、このような自然 景観を定量的に比較し共通する面を取り出すためには、例えば「主 人公(20代女性)の家と最奇り駅の間の街路」といった細かい舞台分 類では他作品に共通する舞台と自然景観を見つけることは困難で、 このような分類は不適切である。舞台分類はできるだけおおまかに、 かつ自然景観の特徴の違いに対応した分類にする必要がある。以上 を考慮して、ここでは通読後の印象をもとに表-2のように分類した 注4)。舞台は大きくまちといなかに分けられ、そのロケーションによ り東京、地方、外国に分けられ、両者のマトリックスで6分類にな る。東京は地名を明記され多くの作品で明らかに東京を舞台にした 場面が見受けられ、他の町と比べて特別でありかつ多くのサンプル がある。一方地方の町はアノニマスで、同一都市ではないが東京に 対する地方都市として一括した。外国は具体的な地名を伴って書か れることが多い。日本にはない場所として童話風挿話の舞台も含め て外国と考えた。このような舞台のカウントは、例えば東京のオフ イス街を舞台とした物事の記述があれば「東京・都心」が1舞台とし た。また会話のなかに一言出てくるだけの場所（例えば「息子が東 京の大学に行っている」）も、登場人物が生活している場所も同じ1 舞台でカウントした。次に、各作品における主な舞台となった場所 を把握するため、登場人物の主な行動が展開する作品内の中心的な 場所を主舞台と名付け、1作品から1主舞台を判断した。

全体の舞台数は 161 , 主舞台数は $55 て ゙$ 平均すると一作品当り約 3 舞 台である。舞台数、主舞台数共に「地方・町」がそれぞれ34,13で最 も多い。次いで「東京·都心」(31,10) が2番目の出現数である（表-2）。 (3) 年代区分 自然景観イメージの経年変化を把握する尺度として は、受賞年とその作品の舞台の推定年の 2 つが考えられる。ここで は個々の作品はその作品が書かれた時代を直接的、間接的に反映し たものと考えられることから受賞年によって年代変化をみる。例え ば過去への回帰か強い作品も、その時代の風潮の中でこそ書かれ評 価されたと考えられる。このような受賞年で作品をみることで、作 品が成立した時代を直接的、間接的に反映した景観が読み取られる。

受賞作品の内容と各期に含まれる作品数を考慮して受賞年を表-3 のように 3 分割する。この区切り年は実際の高度経済成長の終わり (1972)やバブル経済の始まり(1985頃)等より数年ずつ遅れている。I 期の作品にはまだ戦争の記憶が強く、戦後の新体制と高度経済成長 の中で戦中の思い出が端々に出てくる。ா期にあたる70年代末から 80年代末までの期間は、経済的に安定して豊かさが当たり前となっ た風潮での作品群と考えられる。11年間をかけて18作品が受賞し小 説的には不作ぎみであった。続く四期は、高度技術や情報化の進行 していく社会への不安や、過去のものとなった親密な地域社会への
慕情や読み直しが随所にみられる作品群である。表-4に示すように I期に「地方・町」に最も多くの主舞台が持たれたが、東京、地方、 外国に主舞台が散らばる П期を経て、ா期から多くの舞台と主舞台 が「東京・都心」に持たれている。作品当りの舞台数は I期 2.6 II 期 2.8 III 期3.4 と時代が下るに従って增加し、一つの物語の中の生活圈 が多くの舞台にまたがるようになっている。

\section{2 自然景観要素の出現傾向}

(1) 自然景観要素の出現数と出現率 自然景観要素は舞台ごとで記 述の有無をカウントし、舞台内にその記述があれば何回どのように 表現されていたかにかかわらずその舞台における出現頻度を1とし た。これは次の理由による。小説中の言葉は相対的な重みを持ち、 また同じ表現を嫌い異なる言葉で言い換えられたり、陰喻的に表現 されるものもある。そのため、詞句が出現した毎に単純に頻度を数 える作業も、その解釈も難しい。説明する言葉の長さに着目する方 法もあるが18)、本テクストは同一作家による作品群でないので、作 家による表現手法の違いから作品相互を単純に比較できないおそれ がある。一方、小説中の表現から舞台に在る景観の表現の有無を判 断することは客観的にできる。その結果は個々の作品における舞台 の景観の構成を、またその累計としての作品群全体の結果は共通す るか否かで重みづけられた景観の構成を表していると考えられる。

ここで全自然景観要素数を要素ごとに舞台数で割ったものを出現 率と呼ぶ。表-5にみるように、平均すると一作品当たり7.3 要素、一 舞台当たり 2.5の景観要素が書かれている。各要素の出現率は全体 に湖沼以外はおお拉よそ3割前後で、樹花 $>$ 空 $>$ 海 $>$ 森林 $>川>山>$ 田野＞丘＞湖沼という順である。主舞台数で割ると $100 \%$ を超える 出現率の樹花、空は主舞台でなくても書かれる景観要素である。

テクストの偏りについて考察するため、本研究で得られた自然景 観要素の全舞台数に対する出現率を文献2)の校歌に現れた景観の出 現率と比較する(図-1)と、より山、川が少なく、森林、樹花、空、 湖沼が多い。校歌では地域景観の枠組みをうたいあげるとき、教育 理念に沿ってそびえる山や流れる川が引かれると思われる。それに 対して小説では、登場人物たちの生活感覚を説明するために自然景 観が書かれている。ストーリーの展開上その景観はドラマチックで 心象を投影しやすいものが選ばれていると思われる。しかしそれは 読者にとって自然に感じられるような生の模倣として作られる必要 があり、また作者もその景観を表現できる程度それに親しんでいる 必要がある。そこで登場人物、作者、読者を含めた人々の生活感覚 に身近な景観要素が多く書かれていると考えられる。このように小 説群全体では地域景観の大きな枠組みとなるような山の比重は特化 したものではなく、森林や樹花、空、湖沼がより身近で、それに沿 って心象を展開しやすい景観となっている。

(2) 自然景観要素の出現率の年代変化 表-6は要素ごとの出現率を、 表-7は要素の構成比を各期ごとにみたものである。まず舞台当りの

\begin{tabular}{|c|c|c|}
\hline 表-1 & 自然景観要素の分類項目 & 表-2 舞台の分類枠 非台数(主翡台数) \\
\hline யँ & 山とそれを含む䙡合箈 & I.束京・都心 東宗の町なか 31(10) \\
\hline 海 & 海、潜、港、浜など & 郊外_東京のはずれ \\
\hline 川 & 川、川原、川ベりの生手 & 耵方都市、叮 \\
\hline 兵 & 乒と書かれているもの & 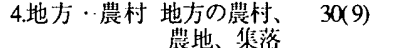 \\
\hline & 斜面烟含む & 外国の浿都級 \\
\hline 湖沼 & 池、湖、沼、泉、湿地 & の都柿 \\
\hline 森杭 & 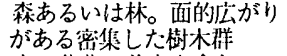 & 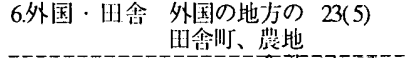 \\
\hline & 木や草花。婁 & 合部 $16 \overline{1}(\overline{5} 5)$ \\
\hline & & \\
\hline
\end{tabular}

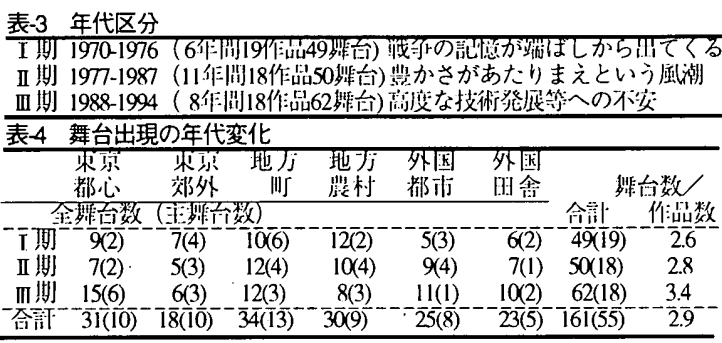

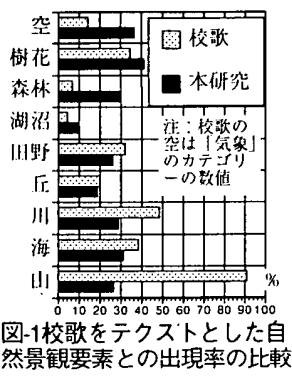


景観要素数は I期 3.04 II 期 2.6 回期 1.95 と時代が下るにつれて減少傾 向にある。次に各要素の出現率の変化をみると山、海、田野は T期 から四期へと減っている。殊に田野と海の四期における減少が急激 である。各期における構成比(表-7)も徐々に減り、山、田野の占め る割合は四期に各々全体の1割を切る。一方構成比が 【期に減り 期に增える景観要素として川、丘、湖沼、森林、樹花がある。出現 率でみても丘は四期に増えている。一方空は咱期で増えて 叫期で減

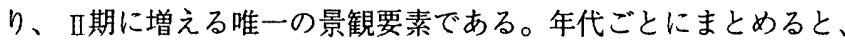
舞台当たりの要素数は年代が下るに従って減少している。要素ごと には、I期は樹花、森林、海、田野、空、川、山がそれぞれ1割以 上シェアしている。【期は山、海、川、田野の出現率かつ構成比が 減少し、空に対してのみ関心が注がれている。四期には丘が増加傾 向にあるが山、海、田野の減少は依然として続いている。

(4) 舞台タイプと要素出現の関連＼cjkstart表-8は舞台タイプごとに自然景観 要素の記述の有無をみたものである。「東京·都心」「地方・町」「外 国·都市」といったまちで自然景観が全くない舞台が多い。一方、 「東京·郊外」を舞台としたものは全て自然景観を伴っている。自然 景観の記述のない舞台は四期に増加していて、特にまちでそれが著 しい。1舞台当たりの要素数を舞台タイプ別にみると、「地方・農村」 「東京·郊外」で共に平均3.5 の自然景観要素の記述がある。「東京·都 心」は0.87と小さい。その変化をみると、「地方·町」「外国·都市」 で減少が大きい。「東京·郊外」「外国·田舎」では四期において最も 要素数が多く、意識的に自然景観を求めているように思われる。次 に表-9は年代、舞台ごとに自然景観要素の出現数を示したものであ る。これをみると I期から四期にかけて減少する山、川、田野は主 に「地方・町」の、海は「地方・農村」のものであり、【期で增加す る空は「地方・農村」「外国・都市」の、四期で増加する丘、森林、 樹花は「東京·郊外」「外国·田舎」のものである。地方が都市化し、 東京郊外や外国の田舎の自然が見直されていると考えられる。また 一般に「東京·都心」「地方・町」「外国·都市」等のまちで樹花や空 が他の要素と比べ出現数が多く、まちで身近な要素と考えられる。

(5) まとめ 特に出現の割合が低い湖沼以外、各自然景観要素の出現 率はほほ3割前後で、突出した景観要素はみられない。時代が下る につれて自然景観の全体の出現数は減少する。その内容をみると山、 川、海、田野が「地方・町」「地方・農村」で一方的に減少し、丘、 㚞林、樹花が四期に「東京·郊外」「外国·田舎」で増加に転じる。 このように一部の地域で一部の景観要素について回復がみられるが
それ以上に地方の都市化が激しいと考えられる。舞台タイプごとに みると、まちで自然景観がない舞台が多く特に四期に増えている。

このように、年代と舞台タイプによって自然景観要素の出現の傾 向に違いがみられた。次に各要素の具体的な書かれ方や付された意 味を各作品の文脈の中で、年代、舞台と関連させてより詳しくみる。

4. 自然景観の意味とその変遷

\section{1 分析の手順}

文脈レベルの分析のために、自然景観の具体的な表現とその意味 内容をまとめたデータベースを作成した。その作業手順を以下に述 ベ、具体例を図-2に示す。

まず、一つの景観要素の表現は幾つもの異なる意味内容を持つこ とがある。このような場合には意味内容を列記した。一方舞台の説 明として景観が提示されているだけで景観に託された意味内容が読 み取られない場合は、意味の出現は 0 とした。意味内容は、視点場 や視対象、景観の構成といった景観の見え方の条件等と、景観に付 随する心象から捉えた。作品の読後感からこのような意味内容を思 いつくかぎりあげ、これをKJ 法によって似た内容のものをできるだ けまとめ、見出しをつけて整理した。このようにして得られた意味 内容のキーワードを図-3に示す。このキーワードがついたデータベ ースを自然景観のカテゴリー、舞台夕イプ、年代ごとに検索して、 共通するキーワードをみることにより、多くの共感に裏付けられた 普遍性の高い心象が得られると考えられる。自然景観要素ごとのキ ーワード集計結果を表-10に示す。ここから自然景観要素の代表的な 意味内容が読み取られる。また、意味内容の出現数が要素出現数よ り多い、山、海、川、丘、湖沼、森林といった要素は意味内容が濃 く、多くの心象を伴った象徴的な景観要素と考えられる。一方田野、 樹花、空といった要素は意味がはっきりしないにも関わらず作品内 に書かれていることから、生活感の演出のために必要な要素と考え られる。次に舞台タイプと年代ごとにみた自然景観要素の意味内容 を表-11に示す。ここから、どんな舞台でどのような意味内容を持っ て書かれているか、また年代によってそれがどう変化しているか読 み取ることができる。このような作業を経て、自然景観要素ごとに、 視点場、視対象、景観の構成、景観に付随する意味を考察した。要 素ごとにまず全体の特徵を述べ、その年代による変化、舞台タイプ ごとに特徴的な共通部分に着目し考察する。

\section{2 要素ごとに託された意味}

(1)山視点場としては平地、山中の両方があり、具体的な視対象と
表 5 自然景観要素ことと出現数と出現率

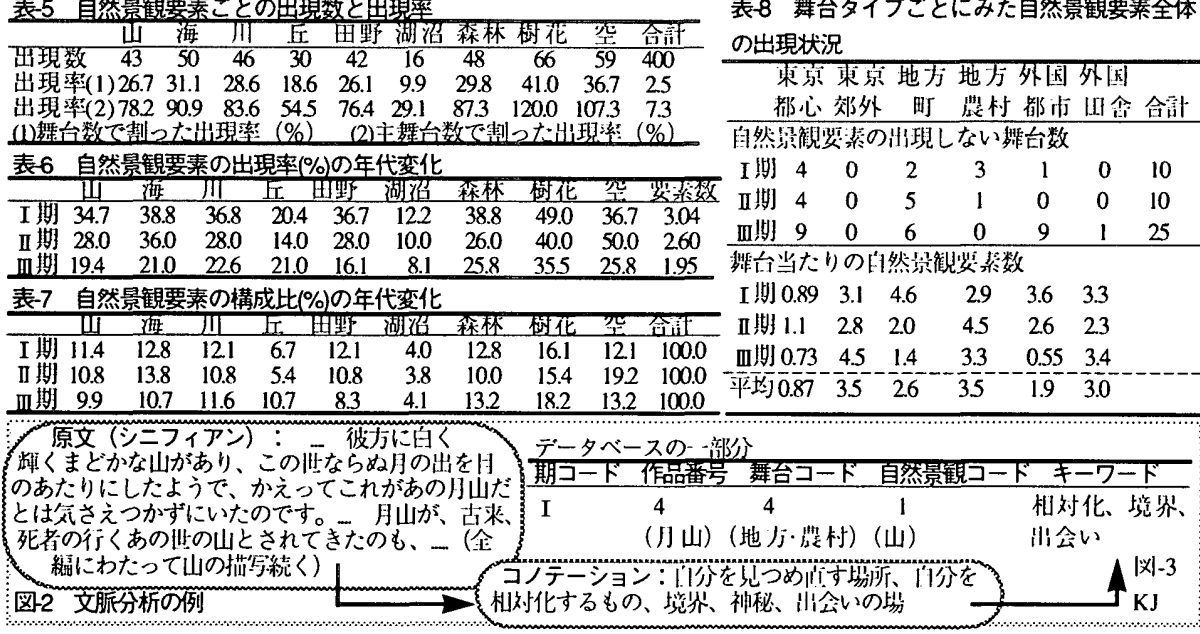

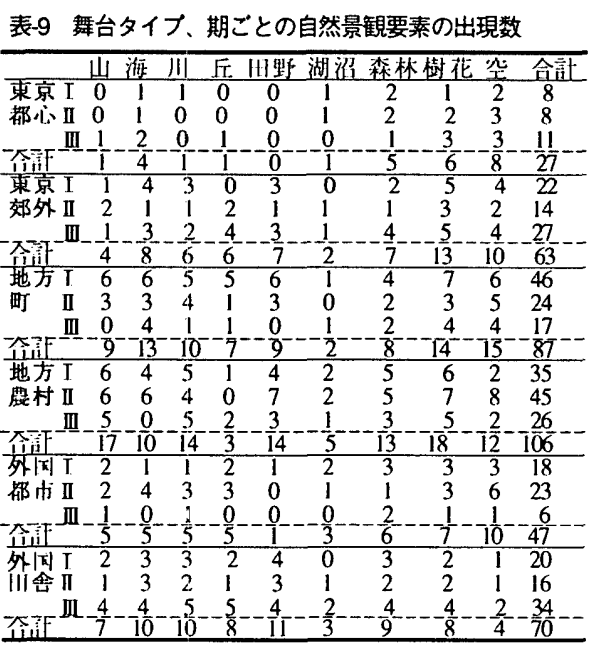


しては山斜面（緑や岩肌）、稜線（空も同時に描写）などがある。 景観の構成としては、町や家を取り巻く山といった描写が多くある。 全体に、山の景観に付随する意味としては生活圏の境界として書 かれているものが多い。また山の重量感や不動の存在感が、いつま でもそこにあるものとして歴史的な時間の感覚を伴ったり、山が見 える土地に結びついた思い出になっている。年代変化をみると、I 期には境界としての山や、山からの眺望の表現が多いが、 期から 回期にかけては話、写真、思い出といった間接的な表現が多くなる。 前章でみた山の出現率の減少と併せると、全体的に山の存在感が薄 れていると言える。舞台タイプごとにみると、山の景観が多く出現 している「地方・町」では、I期には山を越えて別の町に行く、あ るいは山の中に火葬場や墓、被差別部落といった日常生活からは少 し離れた境界的な施設等があるといった表現が多くみられる。【期 からこのような表現が減り、四期に山に関する表現自体がなくなる。 山の開発が次第に進み、山は生活圈の境界としてかつて持っていた 意味を失ったと考えられる。一方「地方・農村」では、期まで境 界としての山が圧迫感を伴ったり規律を支えるものとして「地方． 町」よりさらに厳しく書かれているが、四期になると話としての山 や、採石場や峠に続く道路といった開発後の山の描写に変わってい る。「地方・町」より時期的に少し遅れて、同様に境界としての山 の意味が技術や開発によって薄らいだと考えられる。四期には山の 出現数自体の減少もあって境界に変わる意味が山に付されているか どうかははっきりしない。このように、全体として高度経済成長期 まで山は生活圈の境界として書かれることが多かった。しかし、出 現率の減少と連動するように高度経済成長後はその存在感や意味が 薄れている。現在は山の存在感や意味が曖昧になっていると言える。 (2) 海 視点場としては、海際の海面が見える所、海面は見えないが 音や風や匂いが届く所、山や丘といった眺望地点などがある。視対 象は、浜の砂や岩、海草や生き物、松林、波頭、潮風、海面、船、 港などである。景観の構成としては、海面と合わせて砂と岩が混じ った浜、防風の松林、空が書かれることが多い。

海の景観は多くの場合、遊びや自分を見つめ直すためといった目 的で移動して眺められる、主人公にとっては日常生活を離れた場所 としての意味が託されている。親しい人と行くこともしばしばあり、 その体験やそこでの遊びが思い出になることが多い。年代変化をみ ると、付された意味の変化はよくわからないが視対象となっている 要素の変化がみられる。【期以降、海における労働の姿や、船から 見る景観が書かれていない。四期にはさらに潮の匂い、波音といっ た触覚や聴覚で感じられる海の表現がなくなり、うねる海面や風、 波しぶきなどだけで景観が構成されている。このように経済成長に 伴って、労働や匂い、音を伴ったなまなましい海の姿から、視覚で 眺められるだけの海に変化している。舞台夕イプごとにみると、ま ちでは港の、いなかでは浜の表現が多い。海が最も多く出現する 「地方・町」では、町外れの港とその近くの漁師町、家や飲み屋、 埠頭、浜辺などが書かれている。ここで且期までは遊びに行く場所 として書かれているが、四期には、通りすがりに海がちらりと見え たり開発の話や思い出に絡んで海が書かれるといった出現の仕方に 変化している。行くことを目的として海に行き、海の景観が書かれ るといった表現はなくなっている。一方、次に海の出現数が多い 「地方・農村」では、回期まで浜辺の描写がみられたが、四期には
なくなる。海が開発されて容易に近づけない場所になったと考えら れる。「東京・郊外」では、港と浜の両方が書かれ、「地方・町」 「地方・農村」と似た傾向が併せみられる。このように、全体とし て海は遊びの空間として書かれていたが、高度経済成長後は海へ遊 びに行くことが少なくなり、同時に労㗢や包い、音を伴ったなまな ましい海から、視覚で眺められるだけの表現へ変化している。 (3)川 視点場として橋、川べりなどがあり、また川べりには線路沿 表-10 自然景観要素ごとのキーワード出現数

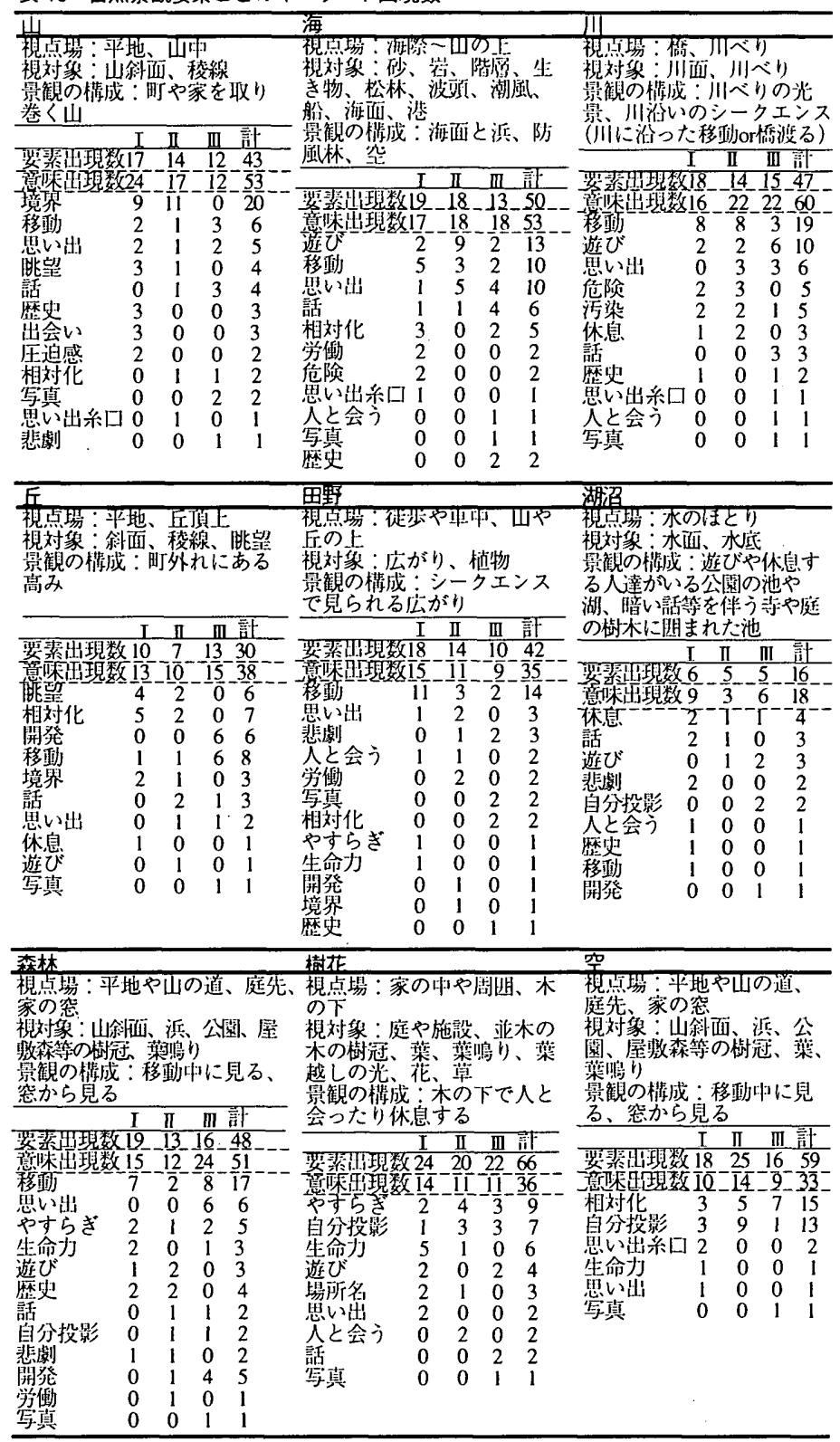

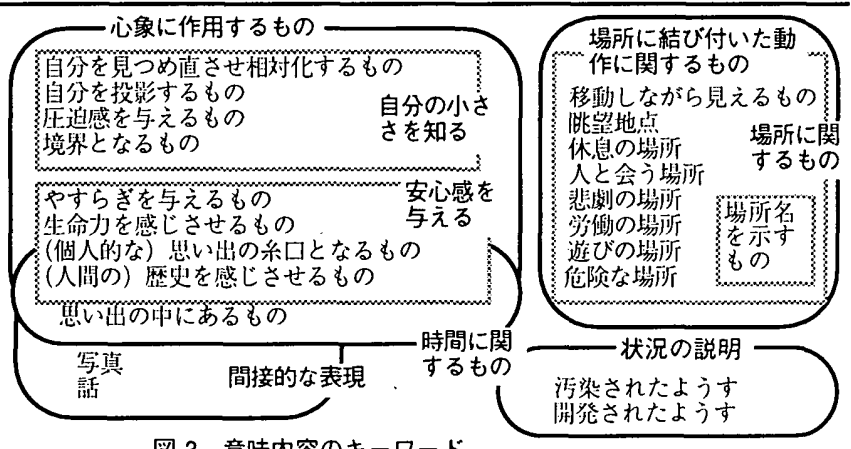

四-3 意味内容のキーワード 
いのものが幾つかあった。視対象は川面の輝きやごみ、流れ、川べ りの土手、草などである。景観の構成としては、川べりに留まって 見る風景、川に沿った移動や橋を渡る移動に伴うシークエンス景観 が多くみられる。川べりでは主人公たちの休息、遊び、会話、出会 いなどの行為が展開する。遊びの内容は釣り、泳ぎ、花見、土手斜 面で遊ぶなどである。このように川べりは遊びの場所であるが、一 方で主人公の友人が溺れたり遊びが禁止されている危険な場所でも ある。また、川沿いは道であることが多くその方向への移動がみら れるが、川に直行すると移動が妨害されて川は境界となる。このよ うに川は遊びと危険、移動とその妨害といった二面性を帯びた景観 要素と考えられる。年代変化をみると、四期になると釣り、萱刈り、 土手での遊びが、幼年期や少年期の思い出として回想されるなど間 接的な川の表現が多い。舞台夕イプごとにみると、川の出現数の最 も多い「地方・農村」では、【期まで川べりの遊びの描写が少なく、 渓谷を橋や川沿いの道から見下ろすといった移動中の描写が多い。 激しい水流、吊り橋、大きな石の河原などが視対象となっている。 四期にはヤマメ釣などの遊びが開発や污染が進んでできなくなった ものとして、失って始めてその重要性がわかったかのように書かれ ている。「地方・町」では、I期から既に污染された水やごみ、ダ ムで水量の少ない川など污い川の景観が書かれ、その後出現数が次 第に減る。一方「外国・田舎」では四期に出現数が増え、会話中に 釣り等が出てくるものが多い。日本にはなくなった美しい川の景観 やそこでの遊びを外国の田舎に求めているように思われる。このよ うに、川は移動とその妨害、遊びと危険といった二面性のある意味 を持ち、川べりは遊びや休息等が展開する場所である。しかしバブ ル期には直接の遊びの体験が減り、遊びの思い出か残っている。

(4) 丘視点場は平地や丘斜面、頂上などで、視対象は、傾斜、稜線、 斜面の植物などであった。丘の上からの眺望の描写も多い。立地と しては町中や外れにある独立した高みが多い。山のように遠くはな 表-11 年代、舞台ことの自然景観要素の意味内容

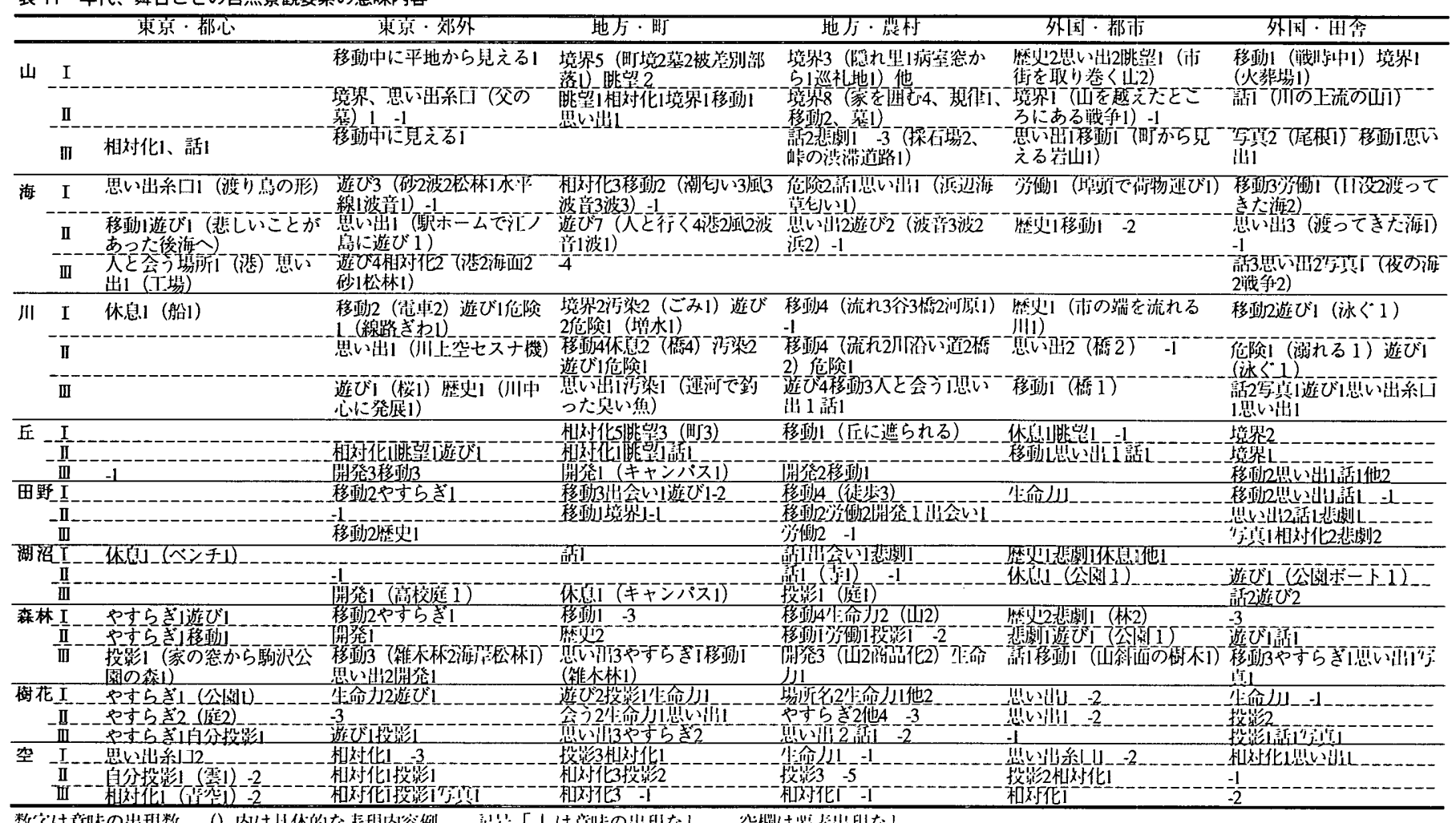

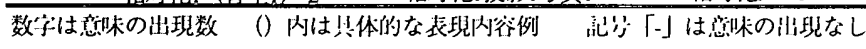

く、学校裏などから手軽に登ることができ、丘頂上に公園やベンチ といった休䕀設備、また日常生活からは離れた施設（火葬場、検疫 所）があるものもある。景観の構成と意味としては、丘の上から町 を眺め自分や人の存在を客観的に町の大きさの中で相対化して感じ るといった表現が多くみられる。主人公は心理的にいきづまった状 態で丘にのほり、町を見渡してそれまでの自分の恼みを小さく感じ る。また山と似て境界としての意味や移動中に見えるものでもある。 年代変化をみると、四期に宅地化等の開発が多く書かれ、それと連 動するように丘の上からの眺望や境界としての表現がなくなる。変 わって丘陵地の上り下りといった移動中の傾斜の描写が增える。丘 が宅地開発されて町を見下ろす視点場がなくなり傾斜のみか残って いると考えられる。舞台タイプでは、「地方・町」を舞台とした丘が I期に最も多かったのが、その後急減する。この頃宅地開発が進み、 町を見下ろす丘の描写がなくなったと考えられる。四期には「東 京·郊外」「外国·田舎」で出現数が增え、丘の全体の出現数のピー クとなる。「東京・郊外」では整地された丘陵地、丘斜面の団地や別 荘地、起伏のある道、「外国·田舎」では思い出の中の道といった書 かれ方をされている。このように生活の場所となった丘の表現が増 える。全体として、高度経済成長期までは「地方・町」における丘 の上からの眺望が多く書かれ、思い立ったときに手軽に登れる自分 を見つめ直す場所になっていた。しかし高度経済成長後は宅地開発 に伴いそのような視点場が失われている。バブル期には「東京·郊 外」を舞台とした宅地化された丘の団地や道の起伏が描写され、生 活の場所に残された傾斜から開発前の自然か涊ばれている。

(5) 田野 視点場は道路や鉄道で、徒歩や車、電車の空から移動中に 見られる景観の描写が多い。また山、丘の上を視点場として見渡さ れるものもある。梘対象は田畑や野原の広がりやそれを覆う植物な どである。景観の構成と意味としては、道路沿いのシークエンスや 山等から見渡される田畑などが、心象を伴わずに舞台の単なる説明 
として記述されていることが多い。年代変化をみると、I期に多か った移動中の描写がその後急減する。開発等が進み、移動の際に周 囲にあった田畑の景観がなくなったと考えられる。舞台タイプでは、 田野の出現は「地方・町」で徐々に減り、四期に0になる。「地方・農 村」でもா期に出現数が減り、同時に田畑の宅地化のようすが描か れる。「東京·郊外」ではアパートなどと混在している緑地が移動中 や丘の上から眺められている。一方、「外国・田舎」に出現する田野 は、大陸の広大な原や田畑、砂漠等であり、思い出やそれまでの日 常生活を破壊するような悲劇の場所といったドラマチックな舞台と して書かれていた。このように、全体として田野の景観は主に「地 方・町」「地方・農村」を舞台として移動中に周囲に当たり前のよう に存在するものであった。しかし高度経済成長後減少している。 (6) 湖沼 視点場は水のほとりで、視対象は湖水面や樹木、空、雲等 の反射、見通せない場合も含め水底のようすなどが書かれている。 景観の構成としては水面への写り込みも併せて湖沼周辺の環境が描 写されることが多い。景観に託された意味は大きく二つに分かれる。 一つは休息や遊びといった行為が展開する明るいイメージの公園の 池や湖で、健康的な遊びの場所である。もう一つは悲劇の場所とな ったり、思い出や歴史を伴う樹木に囲まれた寺や庭園の暗い池のイ メージである。年代変化は、出現数が少なく意味のカテゴリーが多 いので読み取ることが難しい。年代を通じて多様な意味を持ちえる 景観と考えられる。舞台タイプごとにみると、「地方・農村」では木 に囲まれた濁った池や沼が寺境内や庭にあり、出会いや悲劇の場所 となる表現が多い。一方「東京・都心」「地方・町」「外国·都市」「外 国·田舎」では、公園の池でボートや釣りで遊び、ベンチで休息す るといった表現が多くみられる。このように湖沼には、まちや外国 に多い遊ぶ公園の池と、「地方・農村」に多い劇的な出来事の舞台と なる木に囲まれた寺等の池がある。年代変化は特にみられない。

(7) 森林 視点場は平地や山の道や庭先、家の空であり、なかでも道 を視点場として移動中に見られるものが多い。視対象は山斜面の森、 浜の防風林、公園の森、屋敷森などの樹冠、葉、木の葉擦れの音な どである。景観の構成としては、道や家の空から山斜面の森林が仰 き見られるものが多く、他に山等から見下ろされる林、道の両脇の 林、家の中で聞く森の葉擦れの音などがあった。景観の意味として は、移動中に自然に目に入ってくるものとして書かれている他、空 等から主人公が眺めて生命力ややすらぎを感じ物思いにふけるとい うた表現が多い。また山斜面の森は、山の不動感や歴史性を背景と して、不変のもの、四季のめぐりと共に繰り返し可能な、人間を超 えた生命力を感じさせるといった意味を託されていた。一方公園の 森は、都市の中で密な樹冠に囲まれたやすらげる空間としての意味 を持っている。年代変化をみると、山斜面の森が徐々に出現数が減 っている。四期にはそれに変わって思い出としての雑木林が書かれ ることが多い。四期に森林の出現の構成比が増加していて相対的に 重要度が高まっている。舞台夕イプでは、「東京·都心」「東京·郊外」 で神社の森、公園の森、雑木林が書かれている。「東京·郊外」で而 期に増える雑木林は、郊外の団地に引っ越してきてすぐの周囲の林 のようすが多い。「地方・町小「地方・農村」では町の背後や周囲の 山斜面の森が多く書かれている。「地方・農村」で四期に、屋敷森を 切り倒した思い出や、木立に包まれた土地や水が別荘等に商品化さ れるといった表現がある。「地方・町」は亩期に、「地方・農村」はm
期に森林の出現数が減る。このように、全体として山斜面や公園の 森が生命力ややすらぎを感じさせる景観として書かれている。高度 経済成長後の「地方・町」、地方・農村」での出現数の減少に伴って 山斜面の森が減り、「東京·郊外」の雑木林の思い出等の記述が多く なっている。しかしそれまでの意味が失われているわけではなく、 相対的に重要度が増していると考えられる。

(8) 樹花 視点場は空や縁側など家の中や周囲、木の下などである。 視对象は庭の木、花、草などと、並木や公園の木、校庭や病院など の施設の木などである。景観の構成としては、木の下や家の中で感 じる葉ごしの光や葉擦れの音の描写が多い。また木の下は休息の場 所、人と会う場所、場所名を指定する時の目印としても書かれてい る。景観の意味をみると、樹花は主人公の身近にあって、日常生活 の中や物思いに耽っている時などに主人公の視線を受けることが多 い。その時主人公の気持ちなどが樹花に投影されたり、樹花を見た 主人公に安らぎをもたらしたり、生命力を感じさせたりする。樹花 を通して主人公の心理描写が発展することが多い。年代変化をみる と、自分を映すものや話としての樹花は年代が下るにつれて増加す る。場所名を示すもの、思い出、生命力を感じさせるものとしての 表現は減少する。全体の出現数に変動はないが、他の景観要素が減 少しているので、身近な自然景観として相対的に重要度が増してい ると考えられる。舞台タイプごとにみると「東京・都心」では公園 や並木、「東京·郊外」では学校や並木、「地方・町」では庭の樹花が 表現されている。「地方・農村」では場所名の指定に樹木の名が使わ れることがある。このように全体として樹花は身近で自分を投影し たり、休息や安らぎをもたらすものである。年代を通して出現数は あまり変化しないが、相対的に重要度が増していると考えられる。 (9) 空 視点場と景観の構成は舞台により異なる。視対象は、夜（星 月)、夕 (雲、夕焼け)、青空、量り空がある。空もまた樹花と同じ く身近にあり、自分を投影したり、自分を見つめ直すきっかけにな るものである。特に、雲に自分の感情を投影して同化し、青空や夜 空（星月の天体がある）により自分の大きさを見つめ直している。 年代変化をみると、自分を映すものとしての空は П期に出現のピー クがある。他の景観要素が ロ期に出現数が減るため、空の重要度が 増したと思われる。一方自分を相対化するものとしての空は年代が 下るに従って増加している。これも、山や丘といった自分を相対化 する他の景観要素の減少と連動していると思われる。舞台夕イプご とにみると「東京·都心」ではビル屋上や地下鉄出口から、「東京. 郊外」「地方・町」「外国・田舎」では家の庭からや海上の空か眺めら れている。「地方・農村」では山の端と共に見られることが多い。こ のように全体として空は身近にあり、高度経済成長後に自分を投影 する雲、バブル期に自分を相対化する夜空や青空が多く表現されて いる。他の自然景観要素が減少しているため、残された身近な自然 景観である空に相対的に多くの心象が託されるようになっている。

\section{3 まとめ}

全体の傾向として、出現数でみると、1980年代から「地方・町」 で、1990年頃から「地方・農村」で山、海、川、丘、田野、森林と いった要素の出現数が減っている。託された意味についてみると、 山、海、川、丘、森林、湖沼といった要素は多くの心象を伴った象 徵的な景観要素と考えられる。このような山、海、川、丘は高度経 済成長後にそれまで持っていた意味を失っている。一方田野、樹花、 
空といった要素は、あまり心象を託されていない。しかしこの中で 樹花と空は、年代が下るにつれて自分を投影したり見つめ直したり するものといった意味を相対的に多く託されるようになっている。

景観要素ごとにみると、まず山、海、川は年代が下るにつれてそ れまで託されていた意味を失い、かつ出現数が減っている。山は、 高度経済成長期まで生活圈の境界として書かれることが多かった。 しかし、出現率の減少と連動するように、高度経済成長後、その存 在感や意味が薄れている。海は、遊びの空間として書かれていた。 「地方・町」「地方・農村」で経済開発が進んで海へ遊びに行くことが 少なくなり、同時に匂いや音を伴ったなまなましい海から、視覚で 眺められるだけの海の表現へ変化がみられる。川は、移動とその妨 害、遊びと危険といった二面性のある意味を持ち、川べりは遊びや 休息等が展開する場所である。しかしバブル期以降には直接の遊び の体験が少なくなり、遊びの思い出が残っている。

次に、丘は、全体の出現数は減少していないが、託された意味が 変化している。高度経済成長期までは「地方・町」における丘の上 からの眺望が多く、自分を見つめ直す場所になっていた。しかし経 済成長後、宅地開発に伴いそのような視点場が失われている。一方 バブル期に「東京・郊外」を舞台とした丘の団地や道の起伏の描写 が增え、生活の場所に残された傾斜が丘の表現となっている。

また、田野の景観は主に「地方・町」「地方・農村」で移動中に周 囲に自然にあるものであった。しかし経済成長後なくなっている。

一方、このような自然景観要素の減少に伴い、相対的に重要度が 增している要素として森林、樹花、空がある。森林は山斜面や公園 の森が生命力や安らぎを感じさせる景観として書かれ、経済成長後 の「地方・町」「地方・農村」では山斜面の森が減り「東京・郊外」等 で雑木林の思い出等の記述が多くなっている。全体としてバブル期 に構成比と意味の出現数が増えている。樹花は身近で自分を投影し たり、休息や安らぎをもたらすものである。年代を通して出現数が あまり変化せず、相対的に重要度が増していると考えられる。空も 身近で、経済成長後に自分を投影する雲、バブル期に自分を相対化 する夜空や青空が多く表現されている。また湖沼は出現数が少ない が、年代を通じ遊びや劇的な出来事に関わる多様な意味を持ちえる。 5.おわりに

現実をモデル的に表現していて、具体的な表現が普遍性を帯びて いると考えられる1970～94年の芥川賞受賞作品群をテクストとして、 近年の自然景観イメージの解明を試みた。ここではテクストにみら れる自然景観の共通した部分が、日本の近年の自然景観イメージに 関する一般的な意味を表していると仮定している。具体的には自然 景観を山、海、川、丘、田野、湖沼、森林、樹花、空のカテゴリー に分け、その出現傾向及び視点場、視対象、景観の構成、託された 意味内容を明らかにした。得られた特徵を要約すると、地域の枠組 みとなるような山、海、川、丘、田野は出現数あるいは意味が減少、 変化している。一方、空、樹花、森林は身近な景観であり、高度経 済成長期以後は残された景観として相対的に多くの心象が託される 傾向が強まっている。この結果から次のことが言える。

1）思いを託す対象としての自然景観の種類が変化していること

2）変化の全体的な傾向として、地域の枠組みとなるような景観が 要素出現数としてもまた意味出現数としても減少し、都市で身近な 景観要素に相対的に多くの意味が託されるようになっていること。
従って自然景観の多様性が具体的な形でまた意味レベルでも失われ つつあると考えられること

3）バブル期にそれまでの自然景観の減少への反動のように一部の 自然景観要素の出現数が増加に転じる動きをみると、生活の中で自 然景観の必要性が感じられること

本論文で分析されたこのような自然景観の変化は、以下のような 実際の自然景観の変化や自然に対する人々の意識の変化と呼応して いると思われる。

1）地域の自然景観が実際に開発によって失われたこと

2）ライフスタイルなどの変化のために生活空間から遠い場所（作 家にとって実感できない場所）が生まれていること

こうした分析結果を事実として認識することは、景観計画・設計 の方向性の議論や合意形成の場において重要であり、本論文はその 基礎知識の一部を提供したと考えている。

今後の課題として、自然景観は小説のなかに書き込まれた様々な 空間や景観の一部であり、テクスト内には都市や建築に関わる多く のデータがまだ眠っている。今後は別の視点から同テクストの分析 を試みる予定である。

【注】

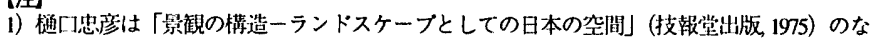

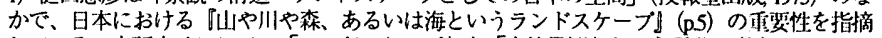
している。本研究はここでの「ランドスケーブ」を自然等㓋という言葉で考える。

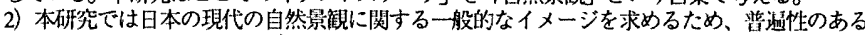
テクストを逝択する。このようなテクスト選択により結果の冓逗性が保祀されると考える。 3）小説の著者の年龄、出身地、居住地などは㑬々の作品の内容に影等していると考えられる

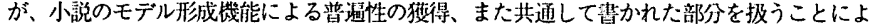
り、著者の属性にのみ左右される部分か排されると考えるので、ここではそれらについて考 察していない。

4)船上や車中といった移動中の景観も、その場所により「外国·田舎」等のそれぞれの舞台 に含めた。分斯椟以外のものは存在しなかった。

\section{【参考文献】論二建然学会計画系論女集、都論二都市計画学会学術研究論文集}

1)萩島哲他4名: 19世紀ヨーロッバ風景絵画にみる都市景観に関する研究，諭, No.413,po.83-93,

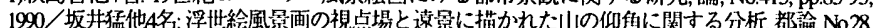
pp505-510, 1993/坂井猛他4名: 広重の浮世絵風景画にみる景観分類に関する研究, 諭, No.461,

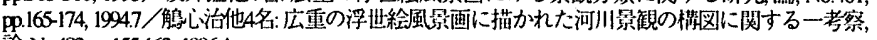
論, No.482,pp.155-163, 1996.4

2)矢部恒楌他2名: 小学校校歌に婹われた全国の地域景観イメージに関する研究。融, №.472,pp.111$122,1995.6$

3)毛利隆子、後藤春彦: 歌にあらわれる『海』のイメージの変容一日本人の海の原風㫫に関す る其整子研究都詥

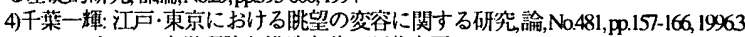

5)YuM ロトマン:文学理諭と慣造主義、頝草指房、1978,pp32-44

のロラン・バルト:物話の棈造分析、みすす㨁房、1979, $\mathrm{ppl} 1-2$

わロラン・バルト:雾度のエクリチュール,みすす饶房 1971,p03040

8)大江健三郎:新しい文学のために、岩波新声、1988,pp2-11,76

9)文献和. pp.192

10)文献5、 pp23-24

11)文献的 $\mathrm{ppR2-87}$

12)文献8 pp.100-10

13) 文献8 p 64

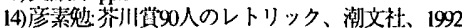

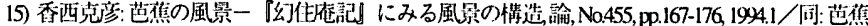

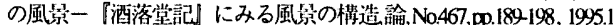

16黑岩俊介、前川通郎: 教会堂の現绿学ーマル七ル・ブルーストの「失われた時を求めて」に

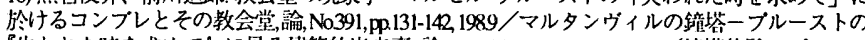
柣われた時を求めて』に胃る建筑的出来事, 論, №.406, pp.153-159,1989.12/鐘塔休験一プルース

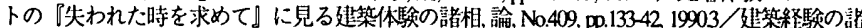
相ープルーストの『失われた時を求めて』におけるサンティレール教会堂の镜塔の場合, 論, No417,pa99-107,1990.11

17) 藤原学: 小説『緗雪』にみられる建築的事象について, 建築学会論文集, №.478, pp.189-197 1995.12

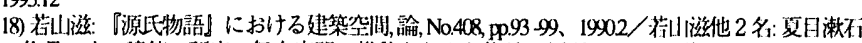

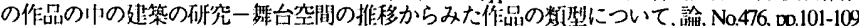

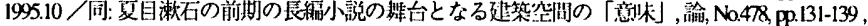
1995.12

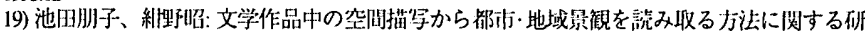

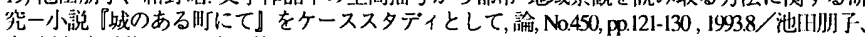

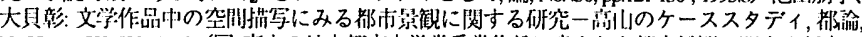

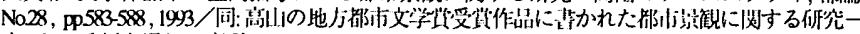
文以“Mの分析を通じて,都論, No29,pp601-606,1994

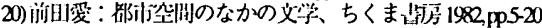

（1996年 7 月 10 日原稿受理，1996年11月27日採用決定） 